\title{
A preliminary study on genetic divergence of the Asian lesser white-toothed shrew Crocidura shantungensis (Mammalia: Soricomorpha) in mainland Korea, adjacent islands and continental East Asia: cytochrome $b$ sequence analysis
}

\author{
Hung Sun Koh*, Irina V. Kartavtseva, Bae Keun Lee, Gu Hee Kweon, \\ Byeng Gug Yang, Seon Wook Heo \& Seong Taek In
}

\begin{abstract}
To examine genetic divergence of Crocidura shantungensis in mainland Korea, adjacent islands and continental East Asia, we obtained 17 complete cytochrome $b$ sequences (1140 bp) from mainland Korea and Far Eastern Russia, and these sequences were compared to sequences of $C$. shantungensis, obtained from the GenBank. Jeju C. shantungensis was divergent from the mainland Korean population, with average genetic distance of 1.94\%. Moreover, Tsushima C. shantungensis was distinct from the mainland Korean population, with average distance of $2.08 \%$, but the latter was not divergent from other C. shantungensis in Taiwan and Ullung islands, Mongolia, southeastern Siberia, and Far Eastern Russia, indicating that three clades (Jeju, Tsushima, and Taiwan-Ullung-continental East Asia) are recognized within $C$. shantungensis. Our results do not support the current subspecies classification of $C$. shantungensis (i.e., C. s. quelpartis from Jeju and Taiwan and C. s. shantungensis from other distribution regions), and do support the former classification of Jeju population as C. s. quelpartis. Thus, we proposed further systematic analysis with additional specimens from East Asia to clarify the taxonomy and phylogeography in C. shantungensis.
\end{abstract}

KEY WORDS: Soricomorpha, Crocidura shantungensis, East Asia, Korea, phylogeography, DNA systematics, cytochrome $b$.

Hung Sun Koh [syskoss@chungbuk.ac.kr], Department of Biology, Chungbuk National University, Cheongju 361763, Korea; Irina V. Kartavtseva [Irina-Kar-52@rambler.ru], Institute of Biology and Soil Science, Russian Academy of Sciences, Vladivostok 690022, Russia; Bae Keun Lee [waterdeer@empal.com], Species Restoration Technology Institute, Gurye 402-031, Korea; Gu Hee Kweon [apodemus92@hotmail.com], Department of Biology, Chungbuk National University, Cheongju 361-763, Korea; Byeng Gug Yang [yangbg@korea.kr], National Institute of Environmental Research, Incheon 404-708, Korea; Seon Wook Heo [obesus@hanmail.net], Department of Biology, Chungbuk National University, Cheongju 361-763, Korea; Seong Taek In [acts219@naver.com], Department of Biology, Chungbuk National University, Cheongju 361-763, Korea.

\section{Предварительное исследование генетической дивергенции азиатской малой белозубки Crocidura shantungensis (Soricomorpha: Mammalia) материковой части Кореи, близлежащих островов и континентальной Восточной Азии: анализ цитохрома $b$}

\author{
Хан Сан Ко, И.В. Картавцева, Бэ Кеунт Ли, Гу Хи Квон, \\ Биёнг Гуг Янг, Сеон Вук Хео, Сеёнг Тэк Ин
}

РЕЗЮМЕ. В результате предварительного исследования генетической дивергенции азиатской малой белозубки Crocidura shantungensis материковой части Кореи, близлежащих островов и континента Восточной Азии, мы получили 17 полных сиквенсов гена цитохрома $b$ (1140 пн) из материковой части Кореи и Российского Дальнего Востока и сравнили их с сиквенсами C. shantungensis, полученными из ГенБанка. Особи C. shantungensis из корейского острова Чеджу дивергировали от материковых популяций с величиной средних расстояний, равных 1,94\%. Кроме того, C. shantungensis с Цусимы отличаются от материковых популяций Кореи (средние дистанции 2,08\%), которые сходны с C. shantungensis островов Тайвань и Уллунь и из материковых популяций Монголии, юговосточной Сибири и Дальнего Востока России, что свидетельствует о существовании внутри вида

* Corresponding author 
C. shantungensis трех клад (Чеджу, Цусима и острова Тайвань-Уллунь-материк Восточной Азии). Наши результаты не подтвердили подвидовую классификацию, принятую в настоящее время для $C$. shantungensis (т.е., C. s. quelpartis из Чеджу и Тайваня и C. s. shantungensis из других регионов), но подтвердили ранее предложенное выделение популяции острова Чеджу в отдельный подвид $C$. $s$. quelpartis. Необходим дальнейший систематический анализ с исследованием дополнительных экземпляров из Восточной Азии для уточнения таксономии и филогеографии C. shantungensis.

КЛЮЧЕВЫЕ СЛОВА: Soricomorpha, Crocidura shantungensis, Восточная Азия, Корея, филогеография, ДНК систематика, цитохром $b$.

\section{Introduction}

The Asian lesser white-toothed shrew (Crocidura shantungensis Miller, 1901) is distributed in southeastern Siberia, eastern China, and mainland Korea, including Taiwan, Jeju (Korea), Ullung (Korea), and Tsushima (Japan) islands (Hutterer, 2005). Six subspecies had been reported: C. s. utsuryoensis from Ullung, C. s. quelpartis from Jeju, and C. s. coreae from mainland Korea (Jones \& Johnson, 1960), C. s. coreae from Tsushima (Thomas, 1908), C. s. orientis from Ussuri region and eastern Siberia (Corbet, 1978), and C. s. hosletti from Taiwan (Jameson \& Jones, 1977). Recently, two subspecies of $C$. shantungensis (C. S. quelpartis from Jeju and Taiwan and C. s. shantungensis from other distribution regions) were recognized (Hutterer, 2005), indicating that subspecies classification of $C$. shantungensis is still in confusion.

Nuclear genes with a slower rate of evolution are useful for the phylogeny reconstruction at a higher level, whereas mitochondrial DNA is more suitable for classification at the species level and for the examination of population structures within a species (Sunnucks, 2000). Molecular phylogeny within six species of Crocidura shrews in northeastern Asia was investigated from partial (402 bp) cytochrome $b$ sequences (Han et al., 2002), and phylogenetic relationships among eight Crocidura shrews in East and Central Asia were analyzed on the basis of complete or partial cytochrome $b$ sequences (Ohdachi et al., 2004), whereas phylogeographic structure within six species of $C$. suaveolens group was examined based on nuclear Breast Cancer Susceptibility 1 (BRAC1) and mitochondrial cytochrome $b$ sequences (Dubey et al., 2006).

From a molecular study with six partial (402 bp) cytochrome $b$ haplotypes of $C$. shantungensis, Jeju population (one haplotype) made a unique local cluster and diverged slightly from other $C$. shantungensis (five haplotypes) in mainland Korea, Ullung and Kagu Islands (Korea), Tsushima, and Taiwan (Han et al., 2002). In a sequencing study of $C$. shantungensis on the basis of complete or partial (402 bp) cytochrome $b$ sequences, one Jeju haplotype was divergent from other six haplotypes of $C$. shantungensis from Primorye (Far Eastern Russia), mainland Korea, and Ullung (Ohdachi et al., 2004), whereas based on one partial (998 bp) cytochrome $b$ sequence from Tsushima and complete eight sequences from other regions, three subgroups of
C. shantungensis were shown (Jeju; Tsushima; and Primorye, mainland Korea, and Ullung) (Dubey et al., 2006). Recently, on the basis of 15 complete cytochrome $b$ haplotypes with different sequences three subgroups of $C$. shantungensis were reported (Jeju and Tsushima; Buryatia, southeastern Siberia; and other regions of Mongolia, Primorye, mainland Korea, and Ullung) (Bannikova et al., 2009), indicating that the previous researches on $C$. shantungensis utilized two partial (402 bp) haplotypes or one complete haplotype from mainland Korea, and their results on population subdivisions are not comparable with one another.

In addition, peripheral populations are often genetically and morphologically divergent from central populations, and natural barriers to dispersal, which limit species distribution, include mountain range and rivers (Goldberg \& Land, 2007). The Yellow Sea separating Korea and eastern China was retreated during the last glacial maximum (Chung, 2007), whereas large areas of continental shelf were dry land at the end of the last glacial period, allowing easy exchange of plant and animal species by land bridge connections to what are now isolated islands (Lomolino et al., 2010). Northern boundary of the Korean Peninsula is formed naturally by Yalu River, Baitou Mountain (the main peak of the Changbai Mountains in northeastern China, $2744 \mathrm{~m}$ above sea level), and Tumen River. Five major populations of $C$. shantungensis (four insular isolates from Jeju, Tsushima, Taiwan, and Ullung and one large continental population from eastern China, eastern Russia, and Mongolia) are surrounding a mainland Korean population.

Moreover, the ancestors of Jeju and Tsushima $C$. shantungensis moved from continental East Asia through mainland Korea to Jeju and Tsushima Islands, respectively (Motokawa et al., 2003). Thus, it appeared that a cytochrome $b$ sequencing analysis using several $C$. shantungensis specimens from mainland Korea is necessary to examine genetic diversity of mainland Korean population and investigate the genetic divergence of a peripheral mainland Korean isolates within the Korean Peninsula from other populations in adjacent islands and continent of East Asia. However, the genetic analysis with more $C$. shantungensis specimens from mainland Korea has not been performed yet.

In this paper we obtained 17 complete cytochrome $b$ sequences (1140 bp) of $C$. shantungensis from four locations in mainland Korea and one location in Far Eastern Russia (Vladivostok), and these sequences were 


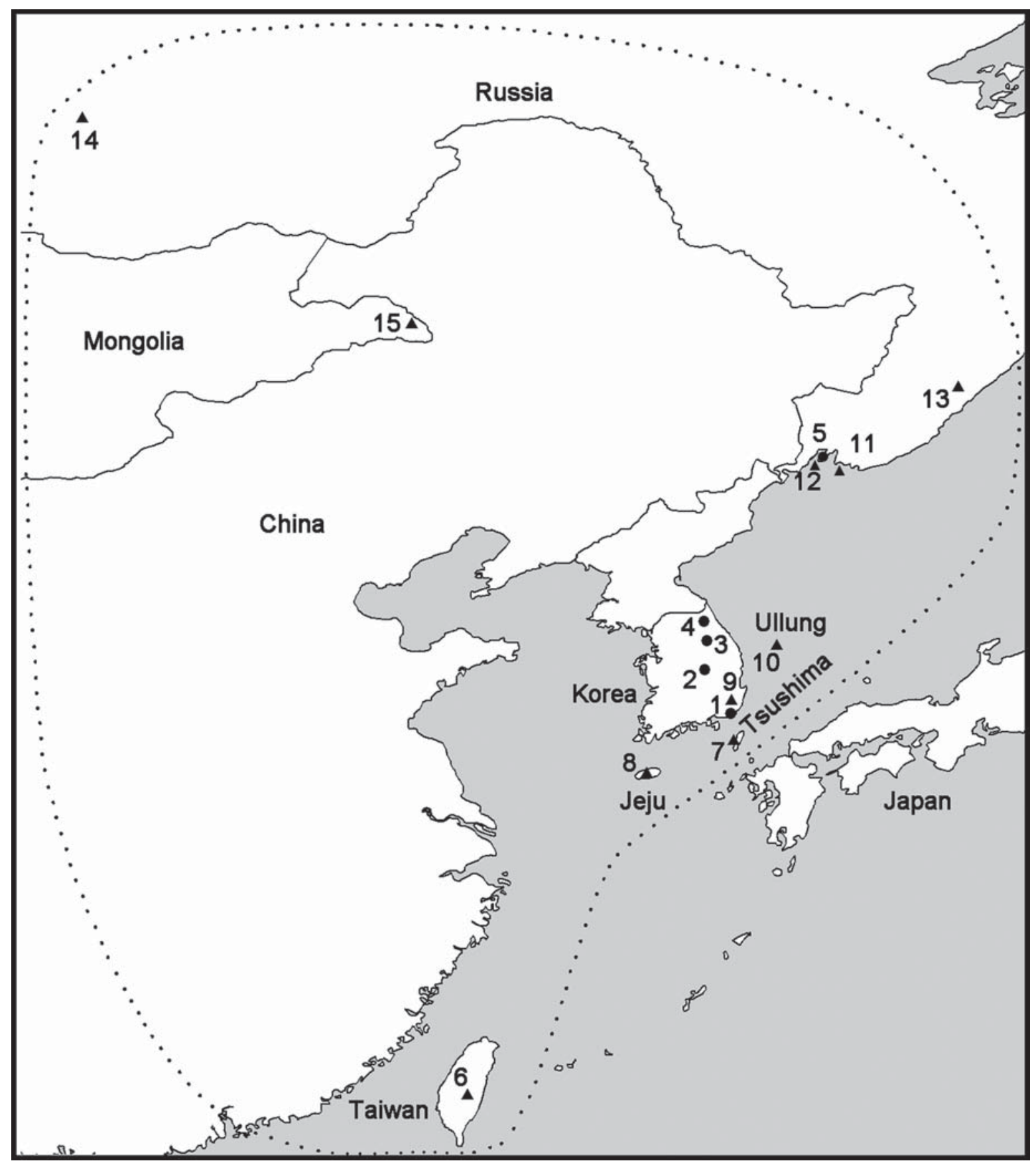

Figure 1. Map showing the distribution range (indicated in dotted line) of Crocidura shantungensis and the localities of studied specimens. The specimens collected during this study are indicated in circles, the specimens from GenBank are indicated in triangles. See locality numbers and additional information in Table.

compared to the corresponding sequences of $C$. shantungensis, obtained from GenBank, in order to examine genetic divergence of mainland Korean population from other East Asian C. shantungensis populations.

\section{Material and methods}

Specimens consisted of 17 C. shantungensis individuals from four locations in mainland Korea and one location in Far Eastern Russia (see Table) were studied. Collection sites are shown in Figure 1. Muscle biopsies were taken and preserved in a deep freezer.

From the muscle samples, total cellular DNA was extracted using a genomic DNA extraction kit (Bioneer Co., Korea). The cytochrome $b$ gene was PCR-amplified, using primers L14724 and H15915, designed by Irwin et al. (1991), and PCR thermal cycle for cytochrome $b$ gene was as follows: $94^{\circ} \mathrm{C}$ for $5 \mathrm{~min} ; 94^{\circ} \mathrm{C}$ for 
Table. List of the specimens analysed for the complete cytochrome $b$ gene sequences (1140 bp). Locality numbers correspond to those in Fig. 1. Haplotype codes correspond to those in Fig. 2.

\begin{tabular}{|c|c|c|c|c|c|}
\hline Specimen No. & Haplotype code & Sampling locality & $\begin{array}{l}\text { Locality } \\
\text { number }\end{array}$ & Accession No. & Source \\
\hline 2560 & Bu01Korea & $\begin{array}{l}\text { Korea, Busan, } \\
35^{\circ} 09^{\prime} \mathrm{N}, 129^{\circ} 07^{\prime} \mathrm{E} \\
\end{array}$ & 1 & KF144152 & This study \\
\hline 2471 & SoOd01Korea & \multirow{10}{*}{$\begin{array}{l}\text { Korea, Mt. Sobaek, } \\
36^{\circ} 54^{\prime} \mathrm{N}, 128^{\circ} 27^{\prime} \mathrm{E}\end{array}$} & \multirow{10}{*}{2} & KF144159 & This study \\
\hline 2472 & So02Korea & & & KF144154 & This study \\
\hline 2473 & So03Korea & & & KF144155 & This study \\
\hline 2474 & So04Korea & & & KF144156 & This study \\
\hline \multirow{4}{*}{$\begin{array}{l}2475,2477 \\
2479,2480\end{array}$} & \multirow{4}{*}{ So05Korea } & & & KF144157 & \multirow{4}{*}{ This study } \\
\hline & & & & KF144157 & \\
\hline & & & & KF144157 & \\
\hline & & & & KF144157 & \\
\hline \multirow[t]{2}{*}{2476,2478} & \multirow{2}{*}{ So06Korea } & & & KF144158 & \multirow{2}{*}{ This study } \\
\hline & & & & KF144158 & \\
\hline 2109 & SoOd01Korea & $\begin{array}{l}\text { Korea, Mt. Odae, } \\
37^{\circ} 47^{\prime} \mathrm{N}, 128^{\circ} 32^{\prime} \mathrm{E}\end{array}$ & 3 & KF144159 & This study \\
\hline 2481 & Se01Korea & $\begin{array}{l}\text { Korea, Mt. Seolak, } \\
38^{\circ} 06^{\prime} \mathrm{N}, 128^{\circ} 28^{\prime} \mathrm{E}\end{array}$ & 4 & KF144153 & This study \\
\hline 2556 & V101FERussia & \multirow{4}{*}{$\begin{array}{l}\text { Russia, Far East, } \\
\text { Vladivostok, } \\
43^{\circ} 08^{\prime} \mathrm{N}, 131^{\circ} 54^{\prime} \mathrm{E}\end{array}$} & \multirow{4}{*}{5} & KF144160 & This study \\
\hline 2557 & V102FERussia & & & KF144161 & This study \\
\hline 2558 & V103FERussia & & & KF144162 & This study \\
\hline \multirow[t]{4}{*}{2559} & V104FERussia & & & KF144163 & This study \\
\hline & FJ814020Taiwan & $\begin{array}{l}\text { Taiwan, Taichung, } \\
23^{\circ} 46^{\prime} \mathrm{N}, 121^{\circ} 02^{\prime} \mathrm{E}\end{array}$ & 6 & FJ814020 & GenBank \\
\hline & DQ630395Tsushima & \multirow{2}{*}{$\begin{array}{l}\text { Japan, } \\
\text { Tsushima Island, } \\
34^{\circ} 25^{\prime} \mathrm{N} 129^{\circ} 20^{\prime} \mathrm{E}\end{array}$} & \multirow{2}{*}{7} & DQ630395* & \multirow{2}{*}{ GenBank } \\
\hline & AY843447Tsushima & & & AY843447** & \\
\hline & AB077078Jeju & \multirow{3}{*}{$\begin{array}{l}\text { Korea, Jeju Island, } \\
33^{\circ} 30^{\prime} \mathrm{N}, 126^{\circ} 32^{\prime} \mathrm{E}\end{array}$} & \multirow{3}{*}{8} & AB077078 & \multirow{3}{*}{ GenBank } \\
\hline & HQ993055Jeju & & & HQ993055 & \\
\hline & HQ709234Jeju & & & HQ709234 & \\
\hline & AB077079Korea & $\begin{array}{l}\text { Korea, Kyengju, } \\
35^{\circ} 50^{\prime} \mathrm{N}, 129^{\circ} 13^{\prime} \mathrm{E}\end{array}$ & 9 & AB077079 & GenBank \\
\hline & AB077075Ullung & \multirow{2}{*}{$\begin{array}{l}\text { Korea, } \\
\text { Ullung Island, } \\
37^{\circ} 29^{\prime} \mathrm{N}, 130^{\circ} 54^{\prime} \mathrm{E}\end{array}$} & \multirow[b]{2}{*}{10} & AB077075 & \multirow[b]{2}{*}{ GenBank } \\
\hline & AB077076Ullung & & & AB077076 & \\
\hline & AB077081FERussia & $\begin{array}{l}\text { Russia, Far East, } \\
\text { Putyatin Island, } \\
42^{\circ} 50^{\prime} \mathrm{N}, 132^{\circ} 25^{\prime} \mathrm{E}\end{array}$ & 11 & $\mathrm{AB} 077081$ & GenBank \\
\hline & AB077278FERussia & $\begin{array}{l}\text { Russia, Far East, } \\
\text { Popov Island, } \\
42^{\circ} 577^{\prime} \mathrm{N}, 131^{\circ} 43^{\prime} \mathrm{E}\end{array}$ & 12 & AB077278 & GenBank \\
\hline & EU742594FERussia & \multirow{2}{*}{$\begin{array}{l}\text { Russia, Far East, } \\
\text { Lazo Nature Reserve, } \\
45^{\circ} 20^{\prime} \mathrm{N}, 136^{\circ} 10^{\prime} \mathrm{E}\end{array}$} & \multirow{2}{*}{13} & EU742594 & \multirow{2}{*}{ GenBank } \\
\hline & EU742593FERussia & & & EU742593 & \\
\hline & EU742584ERussia & \multirow{2}{*}{$\begin{array}{l}\text { Russia, } \\
\text { Buryatia Republic, } \\
53^{\circ} 48^{\prime} \mathrm{N}, 109^{\circ} 20^{\prime} \mathrm{E}\end{array}$} & \multirow{2}{*}{14} & EU742584 & \multirow{2}{*}{ GenBank } \\
\hline & EU742585ERussia & & & EU742585*** & \\
\hline & EU742590Mongolia & \multirow{2}{*}{$\begin{array}{l}\text { Mongolia, } \\
\text { West Khingan, } \\
47^{\circ} 15^{\prime} \mathrm{N}, 119^{\circ} 32^{\prime} \mathrm{E}\end{array}$} & \multirow{2}{*}{15} & EU742590 & \multirow{2}{*}{ GenBank } \\
\hline & EU742589Mongolia & & & EU742589 & \\
\hline
\end{tabular}

\footnotetext{
* partial sequences (1117 bp),

** partial sequences $(998 \mathrm{bp})$

*** partial sequences (1132 bp).
} 
$1 \mathrm{~min}, 57^{\circ} \mathrm{C}$ for $1 \mathrm{~min}$, and $72^{\circ} \mathrm{C}$ for $1 \mathrm{~min}(30$ cycles $)$; and $72^{\circ} \mathrm{C}$ for $5 \mathrm{~min}$. The amplified products were purified using a DNA PrepMate kit with a silica-based matrix at Bioneer Co. (Cheongju, Korea) for the removal of primers and the unincorporated nucleotides. Sequencing of the purified PCR products was carried out using an automated DNA Sequencer (Perkin Elmer 377) at Macrogen Co. (Seoul, Korea).

The complete 17 cytochrome $b$ sequences from mainland Korea and Far Eastern Russia were obtained and compared to the corresponding 17 sequences of $C$. shantungensis from GenBank, as listed in Table.

Sequence alignments, model selections, and tree constructions with 1000 bootstrapped replications were conducted using MEGA5 (Tamura et al., 2011): the Jukes-Cantor (JC) model, which showed the lowest Bayesian information criterion score, was chosen as the best model for our data by the program, and maximum likelihood tree was constructed using the JC model. Crocidura dsinezumi (AB077276) and Sorex caecutiens (JX192950) were used as outgroups.

\section{Results}

From 17 complete cytochrome $b$ sequences (1140 bp) of mainland Korea and Far Eastern Russia C. shantungensis, 12 haplotypes were identified, as listed in the Table. Within the 29 cytochrome $b$ haplotypes of $C$. shantungensis (12 haplotypes from this study and 17 haplotypes from GenBank), 66 sites (5.78\%) were variable and 42 sites $(3.68 \%)$ were parsimony informative.

On the maximum likelihood tree with the 29 cytochrome $b$ haplotypes from $C$. shantungensis (Fig. 2) three subgroups were recognized: Gp 1 (Jeju clade) with three Jeju haplotypes; Gp 2 (Tsushima clade) with two Tsushima haplotypes; and Gp 3 (Taiwan-Ullungcontinental East Asian clade) with 24 haplotypes from Mongolia, Buryatia, Primorye (Far Eastern Russia), mainland Korea, Taiwan, and Ullung. Average JC distances within the Gp 1 and the Gp 3 were 0.53 and $0.64 \%$, respectively.

In addition, the Jeju clade (Gp 1) was divergent from neighboring mainland Korean population (Gp 3, in part), with average JC distance of $1.94 \%$ and 15 fixed site differences (site nos. 67, 126, 127, 151, 321, $411,516,561,618,642,732,771,945,1083$, and 1122), and the Tsushima clade (Gp 2) was divergent from the latter ( $\mathrm{Gp} \mathrm{3}$, in part), with average distance of $2.08 \%$ and 14 fixed site differences (site nos. 126, 243, 411, 468, 498, 618, 732, 771, 822, 924, 1041, 1087, 1107, and 1122): all of the 15 fixed site differences between Jeju and mainland Korean populations were resulted from transition, and only one of the 14 fixed site differences between Tsushima and mainland Korean populations was from transversion.

Additionally, the Jeju clade (Gp 1) was divergent from the Taiwan-Ullung-continental East Asian clade (Gp 3), with average JC distance of $1.82 \%$, and the Tsushima clade (Gp 2) was divergent from Taiwan-
Ullung-continental East Asian clade (Gp 3), with average JC distance of $1.78 \%$.

\section{Discussion}

Insular populations should diverge over time (morphologically and genetically) from populations of respective mainland species (Johnson et al., 2000). Insular Jeju haplotypes of $C$. shantungensis was distinct in the present study with nine complete cytochrome $b$ haplotypes from mainland Korea (Fig. 2) and previous researches with one complete cytochrome $b$ haplotype from mainland Korea (Ohdachi et al., 2004; Dubey et al., 2006; Bannikova et al., 2009). Additionally, one Jeju haplotype was divergent from other haplotypes of C. shantungensis in Far Eastern Russia, mainland Korea, and Ullung, with about $1.0-1.5 \%$ differences by complete or partial (402 bp) sequence analyses (Ohdachi et al., 2004). We found that the Jeju clade (Gp 1) was one of three distinct clades, and that it was divergent from neighboring mainland Korean population (Gp 3, in part), with average JC distance of $1.94 \%$ and 15 fixed site differences, indicating that distinctiveness of the Jeju population was recognized more evidently from this study.

Other insular Tsushima haplotypes of C. shantungensis were distinct with nine complete cytochrome $b$ sequences from mainland Korea (this study: Fig. 2) and with one complete cytochrome $b$ haplotype from mainland Korea (previous researches: Dubey et al., 2006; Bannikova et al., 2009). However, from this study the Tsushima clade (Gp 2) was one of three distinct clades, and it was divergent from the mainland Korean population (Gp 3, in part), with average JC distance of 2.08\% and 14 fixed site differences, indicating that distinctness of the Tsushima $C$. shantungensis was revealed more clearly from this study.

On the other hand, other insular Taiwan and Ullung haplotypes and continental haplotypes from Mongolia, Buryatia, and Primorye formed the TaiwanUllung-continental East Asian clade (Gp 3) together with the mainland Korean haplotypes, as shown in Figure 2. The Buryatia haplotype was reported as a distinct subgroup (Bannikova et al., 2009), but they used no Taiwan haplotypes and only one mainland Korean haplotype for the comparison. In addition, Ohdachi et al. (2004) noted the distinctiveness of Taiwan or Jeju C. shantungensis from other C. shantungensis in Ullung, mainland Korea, and Primorye, with genetic distances of $1.5 \%-2.4 \%$, but they used partial (402 bp) cytochrome $b$ sequences. Thus, we considered that the present analysis, including complete cytochrome $b$ sequences from Taiwan (one haplotype) and mainland Korea (eight haplotypes), is more informative than the previous researches, and concluded that two insular (Taiwan and Ullung) populations and one continental population (from Mongolia to Far Eastern Russia) were not divergent from adjacent mainland Korean population. 


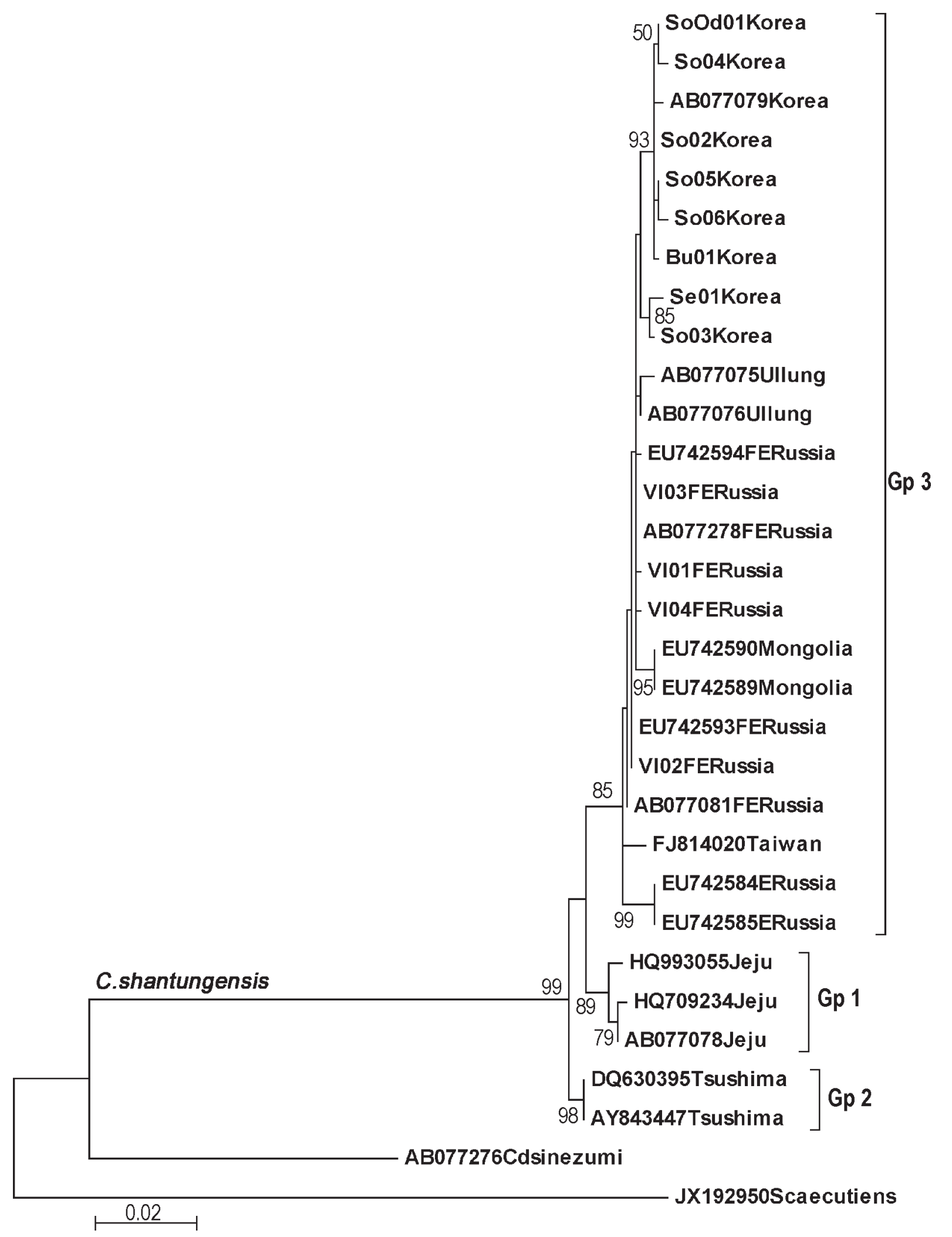

Figure 2. Maximum likelihood tree with 29 cytochrome $b$ haplotypes of Crocidura shantungensis. Specimen number and haplotype codes are listed in Table. The bootstrap values $>50 \%$ are reported at the internodes, and C. dsinezumi (AB077276) and Sorex caecutiens (JX192950) were used as outgroups. 
A subspecies is an aggregate of phenetically similar populations of a species differing taxonomically from other populations of that species (Mayr \& Ashlock, 1991), although it was advocated that a classification should reflect all available characters distributed as widely and evenly as possible over the organisms studied (Huelsenbeck et al., 1996). From a morphometric analysis Jeju (C. s. quelpartis) and Taiwan (C. s. hosletti) populations were average larger than mainland Korean and Tsushima populations (Motokawa et al., 2003), and $C$. s. hosletti was considered as a synonym of $C$. $s$. quelpartis (Hutterer, 2005). However, in this cytochrome $b$ sequence analysis (Fig. 2) Jeju $C$. shantungensis forms a distinct Jeju clade (Gp 1), and it was different from Taiwanese haplotype, indicating that Jeju $C$. $s$. quelpartis is a subspecies with distinct morphology and cytochrome $b$ sequences.

In addition, from this study (Fig. 2) Tsushima $C$. shantungensis forms another distinct Tsushima clade (Gp 2), although C. shantungensis from Tsushima was considered as C. s. shantungensis (Hutterer, 2005) or C. s. coreae (Thomas, 1908). Additionally, Taiwan, Ullung, Mongolia, eastern Russia, and mainland Korean populations formed another Taiwan-Ullung-continental East Asian clade (Gp 3) in this study (Fig. 2), although C. shantungensis from Mongolia, eastern Russia, mainland Korea, Ullung, and Tsushima were also considered as C. s. shantungensis (Hutterer, 2005). Thus, our results appeared not to support the current subspecies classification of C. shantungensis (i.e., C. s. quelpartis from Jeju and Taiwan and C. s. shantungensis from other distribution regions), and do support the former classification of Jeju population as C. s. quelpartis. We proposed further systematic analysis with additional specimens from East Asia to confirm our findings in this study.

\section{References}

Bannikova A.A., Sheftel B.I., Lebedev V.S., Aleksandrov D.Y. \& Muehlenberg M. 2009. Crocidura shantungensis, new species from Mongolia and Buryatia // Doklady Biological Sciences. Vol.424. P.68-71.

Chung C.H. 2007. Vegetation response to climate change on Jeju Island, South Korea, during the last glaciations based on pollen record // Geosciences Journal. Vol.11. No.2. P.147-155.

Corbet G.B. 1978. Mammals of the Palaearctic Region: a Taxonomic Review. London: British Museum (Natural History), Cornell University Press. 314 p.

Dubey S., Zaitsev M., Cosson J., Abdukadier A. \& Vogel P. 2006. Pliocene and Pleistocene diversification and multiple refugia in a Eurasian shrew (Crocidura suaveolens group) // Molecular Phylogenetics and Evolution. Vol.38 P.635-647.

Goldberg E.E. \& Land L. 2007. Species and dispersal barriers // American Naturalist. Vol.170. P.297-304.

Han S.H., Iwasa M.A., Ohdachi S.D., Oh H., Suzuki H., Tsuchiya K. \& Abe H. 2002. Molecular phylogeny of Crocidura shrews in northeastern Asia: a special reference to specimens on Cheju Island, South Korea // Acta Theriologica. Vol.47. P.369-379.

Huelsenbeck J.P., Bull J.J. \& Cunningham C.W. 1996. Combining data in phylogenetic analysis // Trends in Ecology \& Evolution. Vol.11. P.152-158.

Hutterer R. 2005. Order Soricomorpha // Wilson D.E. \& Reeder D.M. (eds.). Mammal Species of the World: a Taxonomic and Geographic Reference. Third edition. Vol.1. Baltimore: Johns Hopkins University Press. P.220311.

Irwin D.M., Kocher T.D. \& Wilson A.C. 1991. Evolution of the cytochrome $b$ gene of mammals // Journal of Molecular Evolution. Vol.32. P.128-144.

Jameson E.W. \& Jones G.S. 1977. The Soricidae of Taiwan // Proceedings of the Biological Society of Washington. Vol.90. P.459-482.

Johnson K.P., Adler F.R. \& Cherry J.L. 2000. Genetic and phylogenetic consequences of island biogeography // Evolution. Vol.54. P.387-396.

Jones J.K. \& Johnson D.H. 1960. Review of the insectivores of Korea // University of Kansas Publication (Museum of Natural History). Vol.9. P.549-578.

Lomolino M.V., Riddle B.R., Whittaker R.J. \& Brown J.H. 2010. Biogeography. Sunderland, MA: Sinauer Associates, Inc. 878 p.

Mayr E. \& Ashlock P.D. 1991. Principles of Systematic Zoology. New York: McGraw-Hill, Inc. 475 p.

Motokawa M., Lin L., Harada M. \& Hattori S. 2003. Morphometric geographic variation in the Asian lesser whitetoothed shrew Crocidura shantungensis (Mammalia, Insectivora) in East Asia // Zoological Science. Vol.20. P.789-795.

Ohdachi S.D., Iwasa M.A., Nesterenko V.A., Abe H., Masuda R. \& Haberi W. 2004. Molecular phylogenetics of Crocidura shrews (Insectivora) in east and central Asia // Journal of Mammalogy. Vol.85. P.396-403.

Sunnucks P. 2000. Efficient genetic markers for population biology // Trends in Ecology \& Evolution. Vol.15. P.199203.

Tamura K., Peterson D., Peterson N., Stecher G., Nei M. \& Kumar S. 2011. MEGA5: molecular evolutionary genetic analysis using maximum likelihood, evolutionary distance, and maximum parsimony methods // Molecular Biology and Evolution. Vol.28. P.2731-2739.

Thomas O. 1908. The Duke of Bedford's zoological exploration in eastern Asia. - VII. List of mammals from the Tsushima islands // Proceedings of the Zoological Society of London. Vol.78. No.1. P.47-54. 